\title{
ОЦЕНКА СОДЕРЖАНИЯ МАКРОЭЛЕМЕНТОВ И МЕЛАТОНИНА В ХРУСТАЛИКАХ ГЛАЗ КРЫС ПРИ МОДЕЛИРОВАНИИ КАТАРАКТЫ
}

\author{
А.Д. Чупров, В.М. Треушников ${ }^{2}$, С.В. Нотова ${ }^{3,4}$, С.М. Ким ${ }^{1}$, \\ T.В. Казакова ${ }^{3,4}$, О.В. Маршинская ${ }^{3,4 *}$ \\ ${ }^{1}$ Оренбургский филиал «НМИЦ МНТК «Микрохирургия глаза» \\ им. акад. С.Н. Федорова» Минздрава РФ, г. Оренбург, Россия \\ ${ }^{2} \mathrm{OOO}$ «Предприятие «Репер-НН», г. Нижний Новгород, Россия \\ ${ }^{3}$ Федеральный научный центр биологических систем и агротехнологий РАН, \\ г. Оренбург, ул. 9 Января, 29, Россия \\ ${ }^{4}$ Оренбургский государственный университет, г. Оренбург, пр. Победы, 13, Россия \\ *e-mail: m.olja2013@yandex.ru
}

РЕЗЮМЕ. Изучен элементный состав катарактальных и некатарактальных хрусталиков глаз крыс. Исследование проведено на крысах Wistar $(n=30)$, из числа которых были сформированы две группы: контрольная и опытная. Животным опытной группы моделировали возрастную катаракту с помощью ультрафиолетового облучения в течение 6 месяцев, после чего осуществляли забор хрусталиков глаз. С помощью атомноэмиссионного и масс-спектрального анализа с индуктивно связанной плазмой изучен химический состав образцов. Выявлено, что с развитием катаракты наблюдается снижение уровня мелатонина, а также дисбаланс макроэлементов в хрусталиках глаз, который сопровождается повышением уровня кальция и натрия на фоне понижения калия, магния и фосфора.

КЛЮЧЕВЫЕ СЛОВА: микроэлементы, мелатонин, катаракта.

\section{ASSESSMENT OF THE CONTENT OF MACRONUTRIENTS AND MELATONIN IN THE LENS OF RAT EYES AT MODELING CATARACTS}

\author{
A.D. Chuprov', V.M. Treushnikov' ${ }^{2}$, S.V. Notova ${ }^{3,4}$, S.M. Kim ${ }^{1}$, T.V. Kazakova ${ }^{3,4}$, O.V. Marshinskaia ${ }^{3,4}$ \\ ${ }^{1}$ N. Fyodorov Eye Microsurgery Federal State Institution of the Russian Ministry of Health, Orenburg, Russia \\ ${ }^{2}$ Research and Development enterprise LLC «Reper-NN», Nizhny Novgorod, Russia \\ ${ }^{3}$ Federal Research Centre of Biological Systems and Agrotechnologies RAS, Orenburg, 29, 9 \\ Yanvarya str., Russia \\ ${ }^{4}$ Orenburg State University, Orenburg, Pobedy ave., 13, Russia \\ *e-mail: m.olja2013@yandex.ru
}

ABSTRACT. In this study, the elemental composition of the cataract and non-cataract lenses of the eyes of rats was studied. The study was conducted on Wistar rats $(n=30)$, from which two groups were formed: control and experimental. The animals of the experimental group were simulated age-related cataracts using ultraviolet radiation for 6 months, after which the lenses of the eyes were taken. The chemical composition of the samples was studied using atomic emission and mass spectral analysis with inductively coupled plasma. It was revealed that with the development of cataracts, there is a decrease in the level of melatonin, as well as an imbalance of macronutrients in the lenses of the eyes, which is accompanied by an increase in the level of calcium and sodium against the background of a decrease in potassium, magnesium and phosphorus.

KEYWORDS: trace elements, melatonin, cataract.

\section{ВВЕДЕНИЕ}

Помутнение хрусталика глаза - одна из наиболее сложных проблем в офтальмологии, которая приводит к развитию катаракты. По оценкам, 95 млн человек во всем мире страдают от данного заболевания (Liu et al., 2017). Согласно литературным данным, макро- и микроэлементы играют важную роль в патогенезе ряда офтальмологических заболеваний, включая катаракту (Dolar-Szczasny et al., 2019). В последние годы также увеличилось количество исследований, доказывающих значимость мелатонина в различных аспектах физиологии зрительного анализатора (Marjan Khorsand et al., 2016).

Цель исследования - изучение элементного состава и содержания мелатонина в катарактальных и некатарактальных хрусталиках глаз крыс. 


\section{МАТЕРИАЛЫ И МЕТОДЫ}

Исследование проведено на крысах Wistar $(n=30)$, из числа которых были сформированы две группы: контрольная и опытная. Животным опытной группы моделировали возрастную катаракту с помощью ультрафиолетового облучения в течение 6 месяцев, после чего осуществляли забор хрусталиков глаз. Элементный статус оценивали посредством изучения химического состава хрусталиков методами ИСПАЭС и ИСП-МС в лаборатории АНО «Центр биотической медицины» (Москва). Определение содержания мелатонина проводили с помощью иммуноферментного анализа с использованием набора Rat MT (Melatonin) ElisaKit. Обработку полученных данных проводили при помощи методов вариационной статистики с использованием статистического пакета «StatSoft STATISTICA 10». Применялись непараметрические процедуры обработки статистических совокупностей ( $U$-критерий Манна-Уитни).

\section{РЕЗУЛЬТАТЫ И ОБСУЖДЕНИЕ}

Установлено, что с развитием катаракты наблюдается дисбаланс макроэлементов в хрусталиках глаз, который сопровождается повышением уровня Са в десятки раз $(p=0,002)$, Na в 1,4 раза $(p=0,12)$ на фоне понижения $\mathrm{K}$ в 1,2 раза $(p=0,07), \mathrm{Mg}$ в 2 раза $(p=0,002)$ и $\mathrm{P}$ в 1,3 раза $(p=0,003)$ относительно животных контрольной группы. Уровень мелатонина хрусталиков в опытной группе был статистически значимо ниже контрольных значений в 1,2 раза $(p=0,039)$.

\section{ВЫВОДЫ}

Генерация активных форм кислорода под действием ультрафиолета приводит к изменению проницаемости мембран клеток и, как следствие, нарушению гомеостаза элементов. Выявленное в эксперименте снижение уровня мелатонина вполне оправдано, учитывая протективное действие этого нейрогормона при индуцировании образования экзогенных активных форм кислорода ультрафиолетовым излучением.

\section{Список литературы / References}

1. Liu Y.C., Wilkins M., Kim T., Malyugin B. Cataracts.Lancet. 2017; 390(10094):600-612.

2. Dolar-Szczasny J., Święch A., Flieger J., Tatarczak-Michalewska M., Niedzielski P., Proch J., Majerek D., Kawka J., Mackiewicz J. Levels of Trace Elements in the Aqueous Humor of Cataract Patients Measured by the Inductively Coupled Plasma Op-tical Emission Spectrometry. Molecules. 2019; 24(22): 4127.

3. Marjan Khorsand, Masoumeh Akmali, Sahab Sharzad, Mojtaba Beheshtitabar. Melatonin Reduces Cataract Formation and Aldose Reductase Activity in Lenses of Streptozotocin-induced Diabetic Rat. Iranian Journal of Medical Sciences. 2016; 41(4): 305-313. 